\title{
Remote Sensing Identification of Possible Meteorite Impact Crater on Ciletuh, West Java
}

\author{
Khairul Ummah ${ }^{1,2, *}$, Emi Sukiyah ${ }^{1}$, Mega Fatimah Rosana ${ }^{1}$, Boy Yoseph CSS Syah Alam ${ }^{1}$ \\ ${ }^{1}$ Faculty of Geological Engineering, Padjadjaran University, Jl. Raya Bandung Sumedang KM 21, Jatinangor 45363, West Java, Indonesia \\ ${ }^{2}$ Faculty of Mechanical and Aerospace Engineering, Institut Teknologi Bandung, Jl. Ganesha 10, Bandung 40132, Indonesia \\ E-mail:*khairulu@gmail.com
}

\begin{abstract}
Ciletuh is a geopark area in West Java that has a semicircle-shaped cliff called mega-amphitheater. Morphogenesis of the amphitheater is still unknown. One possible cause is a meteorite impact that triggered a mega slump. This study aims to collect the evidence of meteorite impact. It has significant value for the geology of Indonesia since this region not yet has confirmed impact crater. In this research, image analysis from satellite remote sensing is used for identification of meteorite impact geomorphology. An analysis based on DEM unveils a ring morphology, a possible clue of an impact crater. The depression zone surrounded by a circular shape with an uplift area in the middle resembles characteristics of the complex impact crater. Meandering Ciletuh river indicates a compression due to a slump towards the southwest. Reconstruction of possible position toward the northeast (before slump deformation occurred) shows a clearer possible meteorite impact crater. A ground checking of identified structure proves that a bowlshaped morphology found at the possible impact crater. Some steep dip structures have found, these might be due to an impact that causes the orientation of the structure to be upright. A stone that resembles the shatter-cone is found in the mélange area. The mélange is believed as a product of a sea trench million years ago. By using meteorite impact theory, it is also possible that the mélange is a kind of impact breccia. This feature adds uniqueness to Ciletuh as a geopark.
\end{abstract}

Keywords - West Java; Ciletuh Geopark; remote sensing; geomorphology; impact crater.

\section{INTRODUCTION}

Ciletuh region is in the southern part of West Java Province (Fig.1). This area is one of the geological sites that has an outcrop of oldest rocks in Java, including ophiolite, sedimentary rocks in the sea, and metamorphic rocks. Furthermore, the composition of various mixed rocks called melange. Due to its uniqueness, Ciletuh has significant value as geology laboratory. In 2015, Ciletuh awarded as one of National Geopark in Indonesia. Ciletuh also has characteristics as global geopark as defined by Krsak et al. [22]. Since April 17, 2018, UNESCO established the Ciletuh-Palabuhan Ratu as an International Geopark [23].

At the edge of the Ciletuh bay area, there is high cliff called mega-amphitheater, because of semicircle shape that resembles the Greek amphitheater. The morphogenesis of the cliff is still unknown. In the research paper, the authors suggest that the Ciletuh valley is the result of thrust fault that later became eroded so that residual sediment of the top formation, in the case is Jampang Formation, cannot be found [1]. The Ciletuh-Jampang area is tectonically located at the south flank of the E-W trending anticline dominating the southern part of Java Island [24]. Land form controlled by geological structure in the Ciletuh area forming elongated hills with steep slopes [25]. However, some researchers stated that the amphitheatre is product of tectonic which is characterized by triangular facets and geomorphic index [2][19][20][21], and the formation of the Ciletuh valley is not because of tectonic fault but a significant move because of a slump, or maybe a meteorite impact [1].

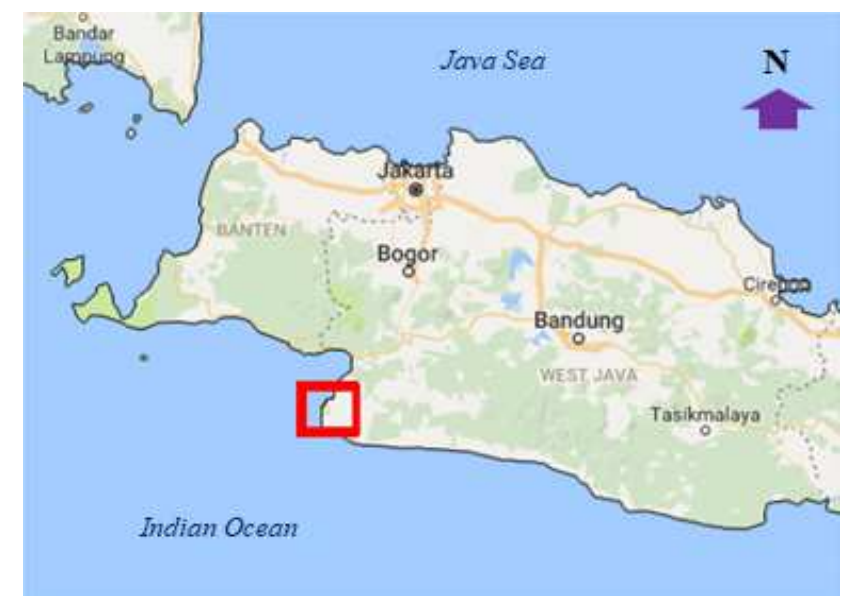

Fig. 1 Ciletuh area is located in the south of West Java Province (red rectangular). 
A mega-slump removes Jampang Formation to the sea, hence exposing older formation [3]. The slump mechanism occurs because of gravitational failure during PliocenePleistocene epoch [4]. Among several theories, the two most popular are a mega slump and a crater by meteorite impact. In this study, the two hypotheses are combined into a hypothesis; i.e. mega-slump which was triggered by a meteorite impact.

This study aims to collect the evidence of meteorite impact. It has significant value for the geology of Indonesia since this region not yet has confirmed impact crater. The study of a meteorite impact in Indonesia is very rare so that this research will be an early initiative for impact crater study in this region. It also will add a significant contribution to the uniqueness of Ciletuh as a geopark.

\section{MATERIAL AND METHOD}

The research focused on amphitheater phenomenon at Ciletuh Bay area. Identification process was using Landsat 7 and SRTM 1 Arc-Second data published by USGS in 2014. In the case, the Arc GIS 10.3 software and other image processing software also used for data processing.

An analysis based on geological condition and impact crater characteristics using remote sensing data to locate most possible impact location in Ciletuh area. Furthermore, the results of the analysis become references in the field investigation.

\section{A. Geological Setting}

The geology of Ciletuh shows evidence of the collision between the Eurasian plate (continental shelf) and the IndoAustralian plate (oceanic plate). In Ciletuh, we can find sedimentary rocks formed in the sea, metamorphic rocks, and igneous rocks (mafic to ultramafic). There is also evidence of mélange rocks as revealed in the Kunti cave. The age of rocks in Ciletuh is estimated as pre-Tertiary age range from 120-65 million years. The appearance of these rocks is the result of tectonic processes. In general, the rocks condition have been fracturing, folding, and faulting. named as the mega-amphitheater. The slope of the cliff is high that it is almost vertical. The difference in altitude between Jampang plateau and Ciletuh valley is approximately 400 meters. The formation process of this amphitheater is still unknown. In the Ciletuh valley, we can find several small hills composed of Pre-Tertiary rocks and Paleogene sediment.

Ciletuh area has a significant contribution to the geology of Indonesia. The pre-Tertiary basement rock is mélange that comparable to the same complex exposed in Luk Ulo area, Central Java. This mélange is a part of the Cretaceous subduction zone in the south of Java.

In the area, the pre-Tertiary rocks classified into three groups, namely ophiolite, sedimentary and metamorphic rocks. The ophiolite consists of gabbro, peridotite, and pillowed basaltic lava. The sedimentary rocks comprise limestone, red shales, greywacke, and chert. The metamorphic rocks consist of phyllite, serpentinite, and blue schist [5].

Based on the morphology, Ciletuh area divided into three formation origins; that are the structure origin morphology, the fluvial origin morphology, and the sea origin morphology [3]. The structure origin morphology has some rounded or tapered hills, such as Gunung Beas and Gunung Badak. This morphology is found from the north to the south, which occupies about $65 \%$ of the Ciletuh area. Generally, this morphology consists of various types of rocks such as ultra basalt, shale, breccia, and phyllite that covered by vegetation. The form of the alluvial plain characterizes the fluvial origin morphology. The distribution of this morphology from the northeast to the south around the Ciletuh River, cover about $25 \%$ of the Ciletuh area. The lithology of this morphology is alluvial sediments, consisting of shale, fine grain sand, and coarse grain sand. This type of morphology is commonly used as settlement, paddy field, and shrimp ponds, such as in Nyalindung and Cikadal areas. The sea origin morphology has coastal-shaped areas that occupy about $10 \%$ of the Ciletuh area. This morphology characterized by the dune that extends in coastal areas of

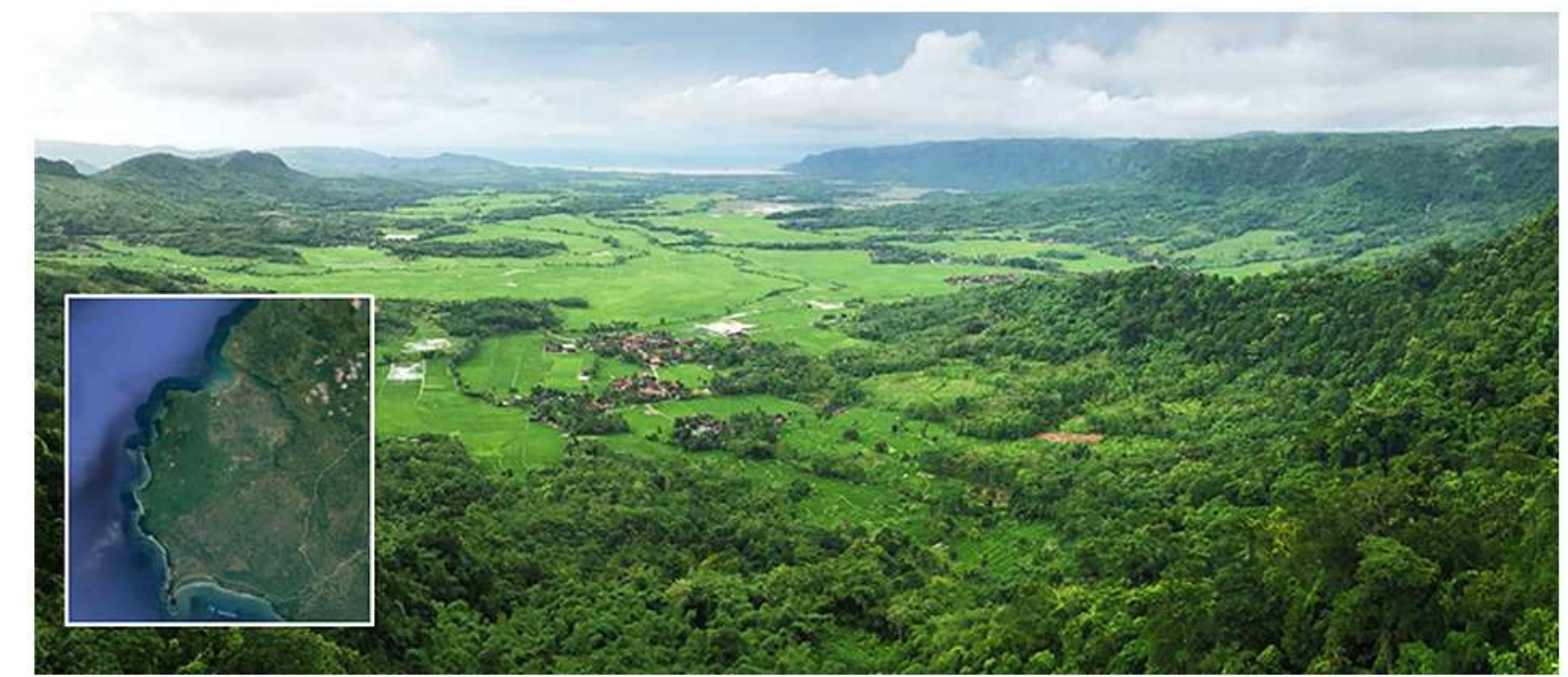

Fig. 2 Ciletuh valley and the mega-amphitheatre (right background). Inset: satellite imagery shows a semi-circular shape of the amphitheatre cliff.

The area of Ciletuh Bay is a large valley bounded by Jampang plateau (Fig.2). The cliff wall forms a horseshoe so
Ciletuh Bay, such as the beaches around Gunung Badak, Cikepuh, and Citireum. 


\section{B. Meteorite Impact and Mega Slump}

Satellite imagery shows a horseshoe wall forming an amphitheater. However, the process of formation of the walls is still a mystery because there is no remnant of Jampang (younger) formation found on top of Ciletuh (older) formation. The theory of mega slump is based on the evidence that in the near of Ciletuh bay there are exposed old rocks like lava pillows and peridotite, but if we move towards southwest, we will find younger sandstone. This indicates that in the old days there was a possibility of younger formation collapse toward the oceanic trench.

Quartz sandstone and basaltic lava units can exposed due to a massive collapse or mega-slump during the PliocenePleistocene period. The geometry of this collapse is like an amphitheater when viewed from above and has spoonshaped when viewed in three dimensions. A gravitational failure might cause this large collapse. In regions are influenced by extensional tectonics, gravitational instability occurs in foot of walls cause sizeable fault blocks rotating. The area affected by gravitational failure will commonly be amphitheater-like in map view, whereas a cross-sectional view will typically display a listric and concave upwards detachment surface [6]. In the research area, the boundary between the quartz sandstone unit and the sandstone unit is a mechanically weak field, so it becomes the detachment field.

Gravity failure is generally associated with a triggering mechanism such as seismic shocks, rapid sedimentation, over-steepening of slopes, changes in pore pressure, or extensional deformation [6]. Ciletuh geological phenomenon raises a hypothesis that an incident had occurred as a trigger of mega-slump. Based on this issue, it is hypothesized that the initial trigger is a meteorite impact. This meteorite size may be relatively small, so the impact only results in a weak zone which later collapses to oceanic trench when a tectonic event occurred after that. The occurrence of a fault during the Pliocene-Pleistocene period is likely to trigger the occurrence of this gravitational failure [3]. Remnants of the current collapse under the amphitheater are likely to be alluvium deposits along with river deposits and coastal sediments in the form of lumps, gravel, sand, and clay.

Several researchers have found meteorite impacts on the continent of Australia. The youngest impact crater confirmed in Australia, Wolfe Creek in Western Australia, has age 0.3 Ma [7]. This age is the same period as Ciletuh amphitheater forming, i.e. Pliocene-Pleistocene. As an area adjacent to Australia, it is possible there has also been a meteorite impact in Indonesia. However, Indonesia is the tectonically active region with many active volcanoes. Therefore, geological process may cover the traces of meteorite impact, either through deformation, erosion, volcanic material covering, sedimentation, nor rock alteration. Coupled with the tropical condition of Indonesia, vegetation can also cover up the traces of meteorite impact at the surface. Because of these, a meteorite impact in Indonesia is likely to have changed, so the characteristics of the remaining traces are not in the perfect form of impact result, such as a circular shape of an impact crater. The characteristics of a meteorite impact that is well recorded in desert regions, such as Australia, chances are unfound in Indonesia. However, it does not mean no characteristic trace is still recognizable. May be several features of the collision remnant left in the shape of a semi-circle; buried basin; impactite such as melted rock, impact breccia, or shattered rock; and radioactive traces, such as iridium and chromium [8]. Impactite cannot found quickly, since its occurrence depends on the size of meteorite, velocity, and the impacted rock [9]. The existence of one or more of these characteristics can support the theory of a meteorite impact in Ciletuh.

\section{Remote Sensing Identification}

The uses of remote sensing data are helpful in early identification of meteorite impacts. Some remote sensing methods usually used as early detection are satellite imagery, aerial photography, and subsurface remote sensing. The use of satellite imagery, for example, has helped the discovery of Xiuyan meteorite crater, the first recognized impact crater in China [10]. The use of aerial photography has also become a way for identification of impact crater such as proposed Bloody Creek impact crater in Canada [11]. Similarly, the use of subsurface remote sensing, i.e. gravity, magnetic, seismic has successfully identified buried craters such as recognized Chixuclub crater in Mexico [12] and proposed Silverpit crater in the UK [13].

The most important of impact crater characteristics are (a) crater morphology, (b) geophysical anomalies, (c) evidence for shock metamorphism, and (d) the presence of meteorites or geochemical evidence for traces of the meteoritic projectile. Morphological and geophysical observations are essential in providing initial information [14]. The use of remote sensing for early identification is helpful to locate a possible area of impactite rocks, such as shatter cones, melted glass, impact breccia, planar deformation features of rock and specific minerals.

In this research, image analysis from satellite remote sensing is used for identification of meteorite impact geomorphology. This study uses Digital Elevation Model (DEM) data from the Shuttle Radar Topography Mission (SRTM) with a resolution of 30 meters. The crater form is recognizable on satellite imagery. The use of DEM helps to recognize morphological anomalies. Satellite imagery analysis also used to distinguish ground surface characteristics, for example by using hyper-spectral data [15].

In search of a meteorite impact, the possible structure is a shape that resembles a crater with a circular pattern because of the collision. Landsat 7 hyper-spectral and panchromatic bands are also to recognize a possible crater basin.

\section{RESULT AND DISCUSSION}

\section{A. Crater Rim}

DEM analysis done for identifies the forms that may be the trace of a meteorite impact. The DEM only provides information about the landside of Ciletuh, did not include the seaside. Hence the search only focuses on landside. All possible ring-like structures are analyzed as possible crater rim. DEM analysis indicates a potential circular shape as a rim of a meteorite crater in the middle of Ciletuh valley (Fig. 3).

The semi-circular shape structure also followed by possible rings around it (zone A). The most interesting about this structure is the presence of a void in the middle between $\mathrm{A}$ and $\mathrm{B}$. This unconformity seems to break the ridge in that 
section. If this structure were purely due to a mega slump which it should be a form of parallel patterns, and no structures with opposite dip orientation. Notice that the structure at location $\mathrm{A}$ has a west-facing direction, while in section $\mathrm{B}$ has an east-facing direction. The existence of the structure $\mathrm{C}$ in the center is also discordant with the existence of other structures. It is estimated that point $\mathrm{A}$ and $\mathrm{B}$ are the edges of the crater (rim) whereas point $C$ is uplift. The uplift is standard feature of a complex impact crater [16].

This semi-circular form cannot be explained either because of volcanic crater because there are no volcanic activity traces in that area. The lithology at each point shows differences that categorized into two groups, i.e. sandstone and basaltic lava. In the A, C, and D zones the lithologies are quartz sandstone. While in B and E zones, the lithologies are dominantly basaltic lava. This lithological difference shows that the semi-circular shape not formed from volcanism but formed after the sedimentation of quartz sand in the area.

This circular shape is not perfect because it has been deformed due to gravitational collapse or by tectonic activity in the area. This is a common phenomenon since impact craters are typically not pristine condition due to partly eroded and/or deformed [17].

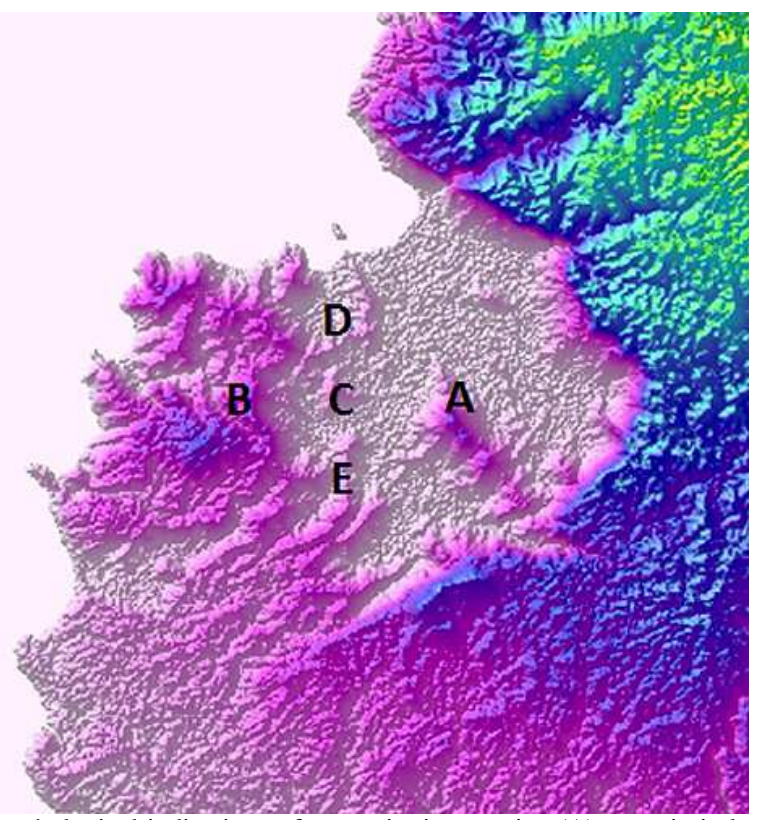

Fig. 3 Morphological indications of meteorite impact; i.e. (A) a semi-circle facing to the west, (B) a semi-circle facing to the east, (C) hill as possible uplift central.

\section{B. Crater Basin}

Hyper-spectral image analysis identify lithology anomaly [15]. Although there are no standards in this analysis, some meteorite impact studies have identified differences in metamorphic rocks because of the collision. However, the studies conducted on a meteorite crater that is still easily recognized. For an eroded and deformed crater, remote sensing may not easily recognize the changes in these rocks.

The hyperspectral data only records the reflection of the ground surface. Hence, the trace of meteorite impacts in the subsurface cannot identified. The use of band combinations to differentiate soil types is not entirely successful, perhaps because of vegetation cover on the surface. Hyper-spectral analysis cannot prove the assumption that a meteorite impact area will have different densities. In this study, the hyperspectral analysis identifies a potential basin below the surface. The basin wills characterized by the presence of alluvial sediment that tends to be wet. A composite image of 1-3-5-7 Landsat 7 hyper-spectral bands combined with the slope of DEM shows a wet area that is interpreted as possible buried crater basin (Fig. 4). The wet area is shown as light green color in the image.

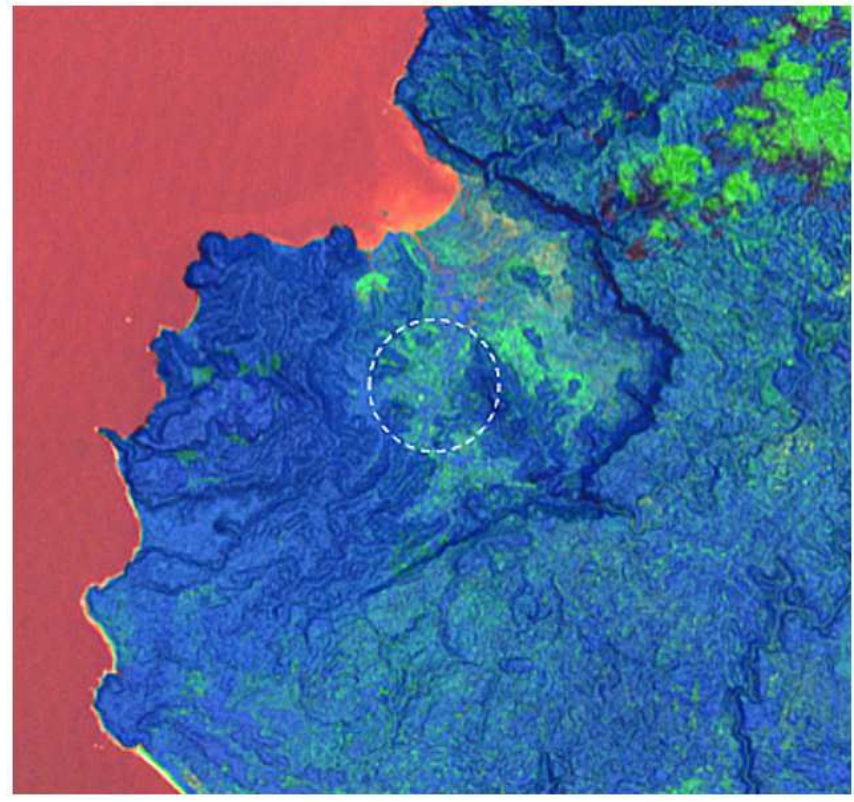

Fig. 4 Composite images of 1-3-5-7 Landsat 7 hyper-spectral bands combined with slope from the DEM shows a wet area interpreted as buried crater basin.

An analysis of the panchromatic image shows a compressed zone which is characterized by the meandering river (Fig. 5). This compressed zone is alleged as an alluvial covered basin. In normal conditions, the river will tend to take the shortest path, so forming a relatively straight path. However, in an area with compression, a river can form meanders. As shown in the satellite image, the Ciletuh River has intense meanders in certain parts. This part suspected to be above of a former meteorite crater.

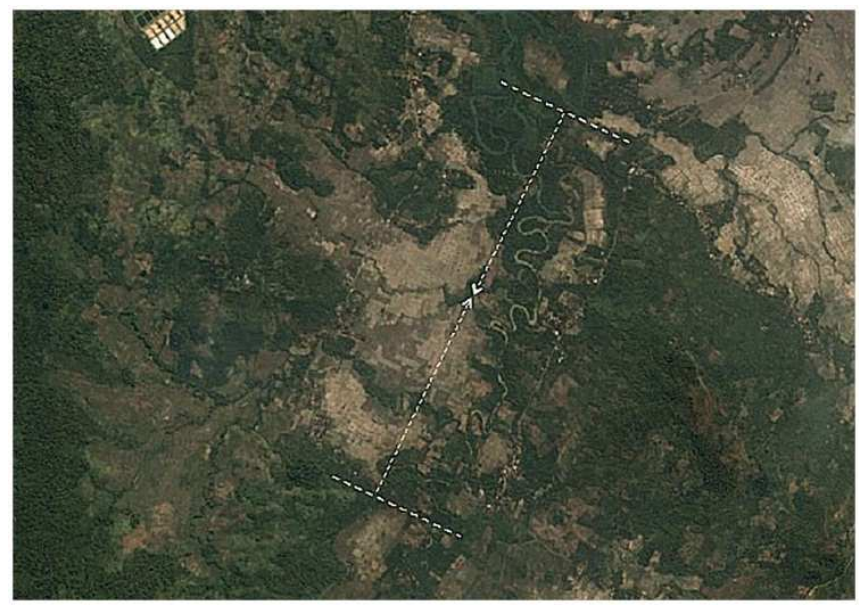

Fig. 5 Meandering Ciletuh River indicates a compression that might be caused by the presence of subsurface basin. 


\section{Impact Location}

Satellite imagery shows a depression zone surrounded by a circular shape with the bulge area (uplift) in the middle. This morphology resembles the characteristics of a complex impact crater. Meander of Ciletuh River indicates a compression due to the movement towards the southwest. That indication show fault lineaments have the direction of NE-SW and NW-SE [4].

Based on the movement towards the southwest, it is possible to recreate old structure by repositioning the structure back to the northeast. The reconstruction will show a more circular shape resemble a meteorite crater (Fig. 6). To reconstruct appropriately, it must consider the paleotectonic in that area also the gravitational collapse mechanism.

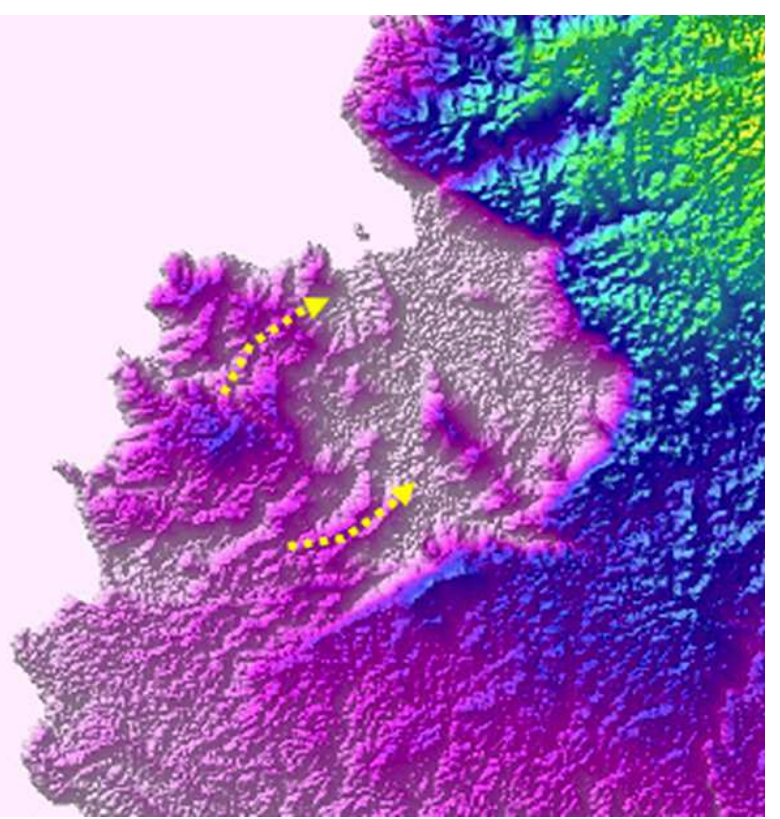

Fig. 6 One possible reconstruction can be done by repositioning the structure back to the northeast. It will show a more circular shape if some ridges in the southern area are connected to the hill at the eastern area.

An analysis using a radius from semi-circle amphitheater will locate a possible impact center (Fig. 7). Impact at this location may cause some cracks that become several today's waterfalls around the Ciletuh bay area. Crack towards south- east might be become the modern Ciletuh River with its Puncak Manik waterfall.

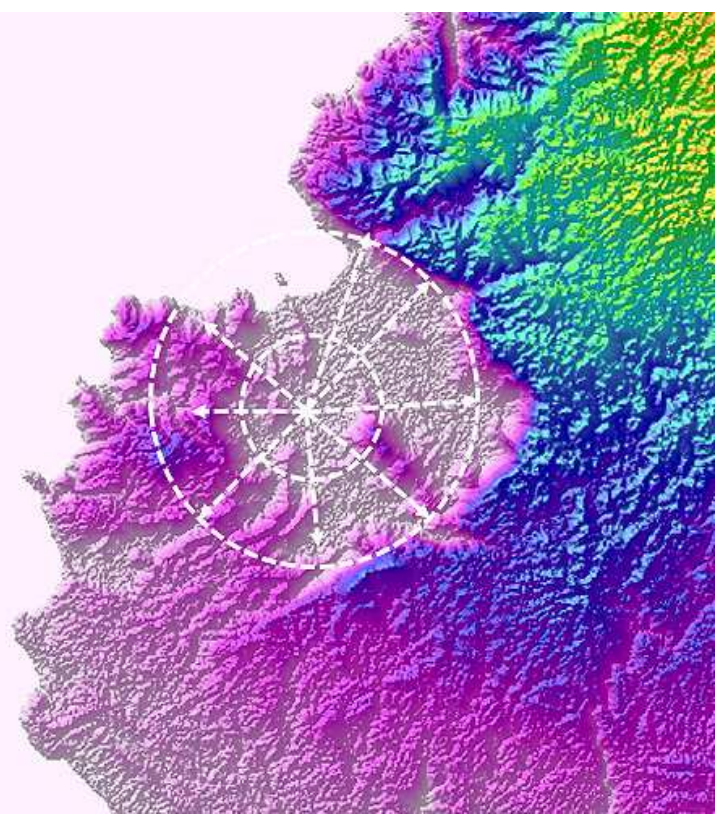

Fig. 7 The possibility of an impact point with a hypothetical outward blast that creates some cracks at the amphitheater.

A 3D view of suspect location shows clearly bowl shape morphology. This shape disrupts the ridges in this area (Figure 8). An interesting morphology can be seen in the zone A, where the hill forms 3 peaks, while the southern part of zone $\mathrm{E}$ has ridges that might have been previously aligned with hilltops in zone A. If this is true, then this indicates that a deformation has occurred in zone E. In the central part, hills in zone $\mathrm{C}$ and ridge in zone $\mathrm{E}$ have different lithology, indicating that these two zones are unrelated. Zones A, C, and D have quartz sand lithology dominantly, while the B and $\mathrm{E}$ zones are areas with older rocks such as basaltic lava.

\section{Ground Check}

After remote sensing analysis, a field trip conducted to investigate the identified structures. Ground checking of identified structure proves that a bowl-shaped morphology found at the possible impact crater (Fig. 9).

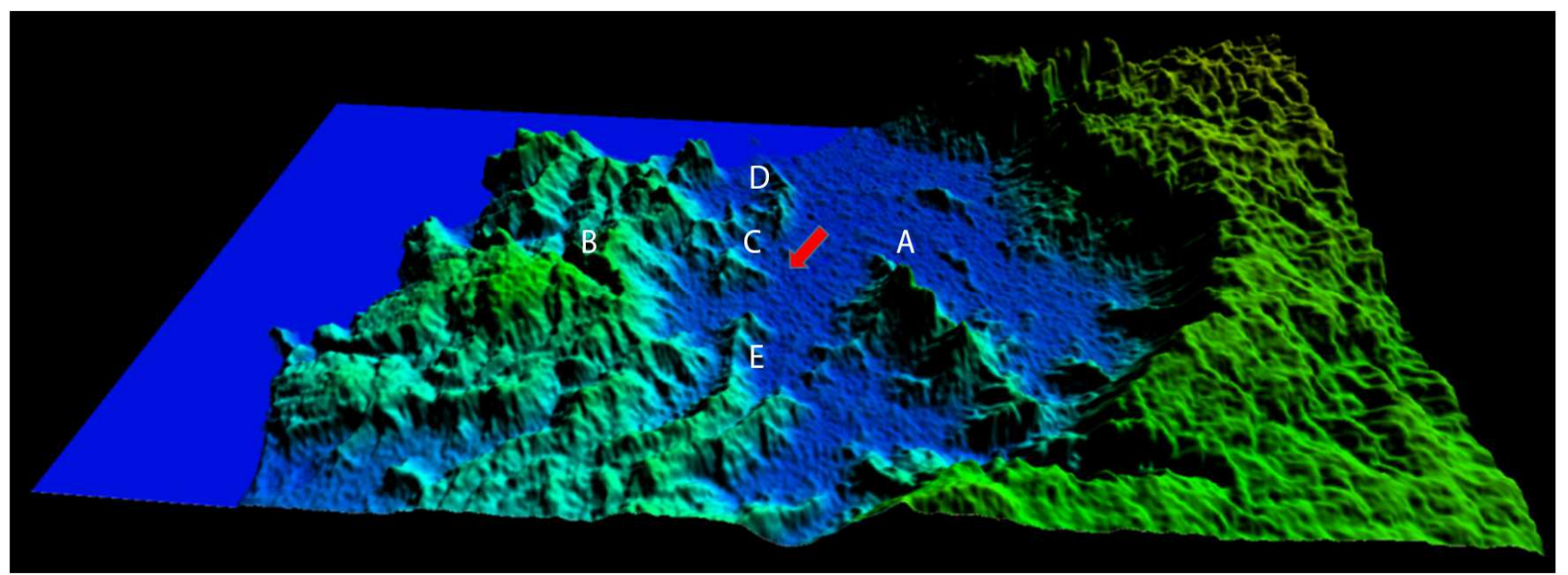

Fig. 8 The 3D view of suspected impact location shows a bowl-shape morphology. 


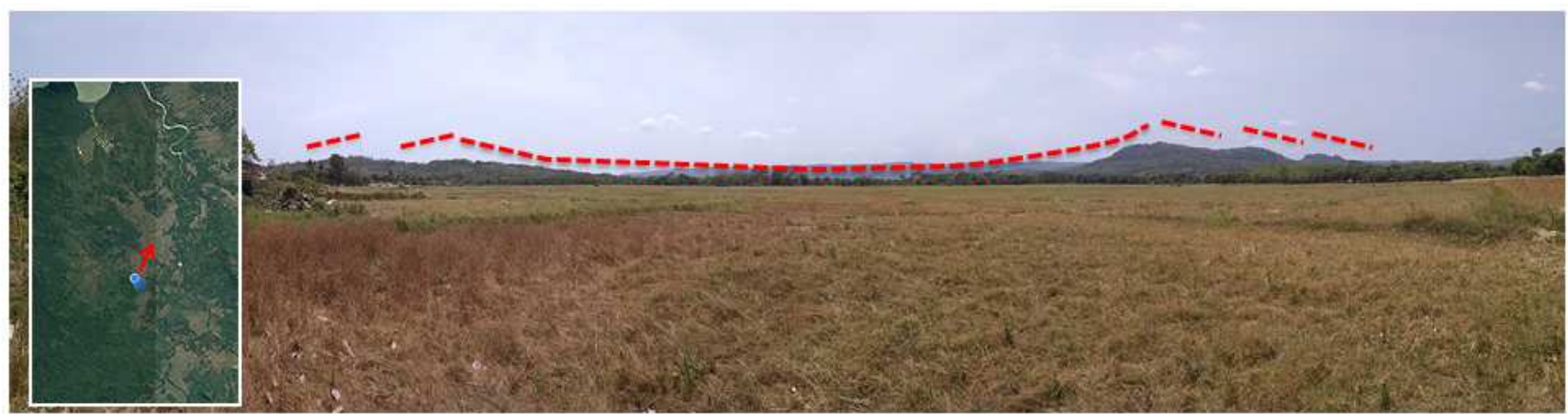

Fig. 9 A bowl-shape morphology shows an opposite-dipping structures (background). Inset: location of taken photograph, at the south of depression zone facing to the north-east.
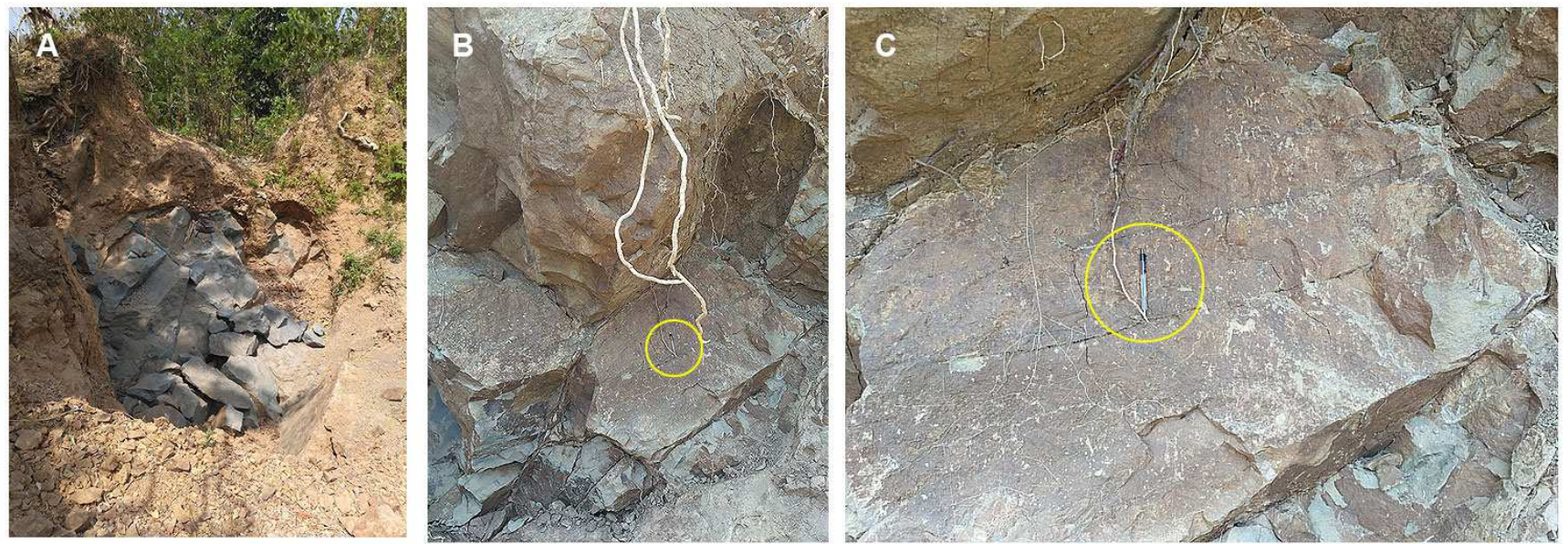

Fig. 10 A rock mining site at the north-west hill shows an exposed rock (A). The sediment rock has steep joint dip about $70^{\circ}$ (B). A detail of the rock (C) shows intense joints that might by impact energy (a ballpoint in yellow circle for scale).

Some northern and eastern areas are accessible because they are paddy fields and settlement areas. While southern and western areas are difficult to access because it is a restricted military training ground and nature conservation.

From inside of the depression zone, it can be seen the hills surrounding the paddy fields. These hills form a structure with an opposite direction that known from its dip. Fig. 9 shows the opposite dipping between the hills on the east side and the west side.

In the north-west, there are hills with stone quarries. The outcrop on one of the rock mine shows sedimentary rocks

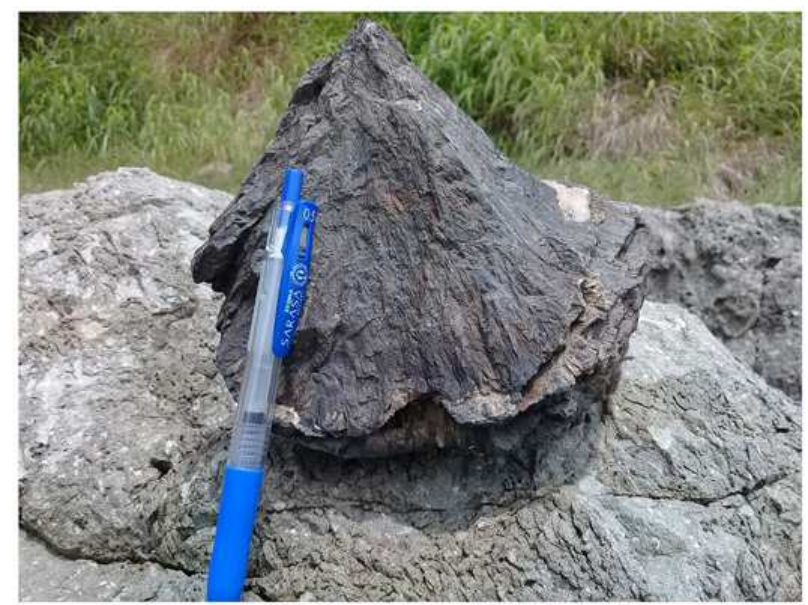

Fig. 11 A shatter-cone like rock at the north-western hill. with very steep joint dips, around $70^{\circ}$. This steep dip structure might be due to an impact that causes the orientation of the structure to be upright (Fig. 10).

The most challenging task in impact crater searching is to find impactite rocks. The possibility of finding these rocks is quite low [14]. Based on the possible crater dimension in this area (about 5 kilometers diameter), the most probable impactite rock can be found in this area is a shatter-cones rock which is caused by a relatively low meteorite impact energy about $2 \mathrm{GPa}$ [18]. By focusing on this type of rock, some specimens which resemble the shatter-cone are collected. One of them (Figure 11) is found at the hill nearby Kunti cave, about 5 kilometers on the north-west of the suspected impact location. This area is known as mélange site. The mélange is believed as a product of a sea trench million years ago. The using meteorite impact theory, it is also possible that the mélange is a kind of impact breccia.

The phenomena found in the field are consistent with the alleged meteorite impact theory. Because this research is still in its early stages, further research is very necessary with a more complete method.

\section{CONCLUSions}

The morphogenesis of Ciletuh amphitheater has been studied in this research through a meteorite impact theory. A meteorite impact is believed to be the initial trigger of a mega-slump that led to the formation of mega-amphitheater. Analysis of the structure using digital elevation model (DEM) from Shuttle Radar Topography Mission (SRTM) has shown 
a shape that resembles a meteorite impact remnant. The analysis shows a depression zone surrounded by a circular shape with the bulge area (uplift) in the middle, like the meteorite complex crater. In the depressed zone, a meandering Ciletuh river indicates compression due to a movement towards the southwest. This geomorphological analysis shows initial evidence of a possible meteorite impact on Ciletuh. This feature adds uniqueness to Ciletuh as a geopark.

\section{ACKNOWLEDGMENT}

The authors are thankfull to Laboratory of Geomorphology and Remote Sensing, Faculty of Geological Engineering, Padjadjaran University for data processing and facilities used in this study. To the rector of Padjadjaran University, we also thank you for the support in the research process through the RKDU grant 2017-2018.

\section{REFERENCES}

[1] B. Clements, R. Hall, H. R. Smyth, and M. A. Cottam, "Thrusting of a volcanic arc: a new structural model for Java," Petroleum Geoscience, vol. 15, pp. 159-174, 2009.

[2] I. Haryanto, "Evolusi tektonik Pulau Jawa bagian barat selama kurun waktu Kenozoikum [Tectonic Evolution of Western Java during Kenozoikum Era]," PhD Dissertation, Faculty of Geological Eng., Padjadjaran Univ., 2014.

[3] M. F. Rosana, U. Mardiana, I. Syafri, N. Sulaksana, I. Haryanto, "Geologi kawasan Ciletuh, Sukabumi: karakteristik, keunikan, dan implikasinya [The geology of Ciletuh, Sukabumi: characteristic, uniqueness, and implication]," Research Workshop and Postgraduate Program Development, FMIPA Padjadjaran Univ., 2006.

[4] K. S. A. Nugraha, "Tektonostratigrafi daerah Taman Jaya dan sekitarnya, Sukabumi, Jawa Barat [Tectonostratigraphy of Tamanjaya Area and Surroundings, Sukabumi West Java]," bachelor's thesis, Faculty of Geological Eng., Padjadjaran Univ., 2016.

[5] A. H. Satyana, "New Consideration on the Cretaceous Subduction Zone of Ciletuh - Luk Ulo - Bayat - Meratus: Implication for Southeast Sundaland Petroleum Geology," $38^{\text {th }}$ Annual Convention Proceedings, Indonesian Petroleum Association, p. G-129, 2014.

[6] J. Hesthammer, and H. Fossen, "Evolution and geometries of gravitational collapse structures with examples from the Statfjord Field, northern North Sea," Marine and Petroleum Geology 16, pp. 259-281, 1999.

[7] C. O'Neill, and C. Heine, "Reconstructing the Wolfe Creek meteorite impact: deep structure of the crater and effects on target rock," An International Geoscience Journal of the Geological Society of Australia, vol. 52, Issue 4, 2005.

[8] S. P. Wright, L. L. Tornabene, and M. S. Ramsey, "Remote sensing of impact craters," Impact cratering: processes and products, Blackwell Publishing Ltd, pp. 194-214, 2013.

[9] K. Wünnemann, G. S. Collins, G. R. Osinski, "Numerical modeling of impact melt production in porous rocks," Earth and Planetary Science Letters 269, pp. 529-538, 2008.
[10] M. Chen, "Impact-derived features of the Xiuyan meteorite crater," Chinese Science Bulletin, vol. 53 no. 3, pp. 392-395, 2008.

[11] I. Spooner, G. Stevens, J. Morrow, P. Pufahl, R. Grieve, and R. Raeside, "Identification of the Bloody Creek structure, a possible impact crater in southwestern Nova Scotia, Canada," Meteoritics \& Planetary Science 44, Nr 8, pp. 1193-1202, 2009.

[12] K. O. Pope, S. W. Kieffer, and D. E. Ames, "Empirical and theoretical comparisons of the Chicxulub and Sudbury impact structures," Meteoritics \& Planetary Science 39, Nr 1, pp. 97-116, 2004.

[13] M. T. Wall, J. Cartwright, and R. J. Davies, "An Eocene age for the proposed Silverpit Impact Crater," Journal of the Geological Society, vol. 165, pp. 781-794, 2008.

[14] C. Koeberl, "Remote sensing studies of impact craters: how to be sure?", Geoscience 336, pp. 959-961, 2004.

[15] F.F. Sabins, "Remote sensing for mineral exploration," Ore Geology Reviews 14, pp. 157-183, 1999.

[16] R. A. F. Grieve, and A. M. Therriault, "Observations at terrestrial impact structures: Their utility in constraining crater formation," Meteoritics \& Planetary Science 39, Nr 2, pp. 199-216, 2004.

[17] J. G. Spray, H. R. Butler, and L. M. Thompson, "Tectonic influences on the morphometry of the Sudbury impact structure: Implications for terrestrial cratering and modeling," Meteoritics \& Planetary Science 39, Nr 2, pp. 287-301, 2004.

[18] G. R. Osinski and L. Ferrière, "Shatter cones: (Mis)understood?", Science Advances, vol. 2, no. 8, e1600616, 2016.

[19] E. Sukiyah, A. Mulyo, I. Syafri, M. Sulastri, and P. Setiyanto "Morfotektonik dan potensi gerakan tanah di kawasan Ciletuh Jawa Barat [Morphotectonic and landslide potency in Ciletuh area, West Java]", Publikasi Ilmiah Pusdiklat Geologi, vol. 11 no. 2, pp. 33-43, 2015 .

[20] Aceng Jaenudin, "Karakteristik morfotektonik DAS Ciletuh Kecamatan Ciemas Kabupaten Sukabumi Provinsi Jawa Barat [Morphotectonic characteristic of Ciletuh Watershed, Ciemas subdistrict, Sukabumi district, West Java province]", Bachelor's thesis Faculty of Geological Eng., Padjadjaran Univ., 2016.

[21] Aloysius Davin, " Morfometri DAS Ciletuh dan hubungannya dengan litologi di daerah sekitarnya [Ciletuh Watershed Morphometry and its relationship with lithology in the surrounding areas]", Bachelor's thesis Faculty of Geological Eng., Padjadjaran Univ., 2016.

[22] Y. Yanuar, Z. Anna, P. Hindayani, MF. Rosana, A. Sudradjat, and Z. Zakaria, "Prospective analysis of sustainable development strategy of Geopark tourism of Ciletuh-PalabuhanRatu West Java Indonesia," International Journal of Current Innovation Research, Vol. 4, Issue 2(A), pp. 1033-1039, 2018.

[23] (2018) Universitas Padjadjaran website [Online]. Available: http://www.unpad.ac.id/2018/04/unesco-tetapkan-ciletuh-sebagaigeopark-dunia/

[24] N. Sulaksana, I. Haryanto, E. Sukiyah, and A. Sudradjat,"On the geomorphology and tectonic position of Ciletuh-Jampang area, West Java, Indonesia", the Conference organized by Asia Oceania Geological Society (AOGS), held in Singapore 4-7 August, 2015.

[25] E. Sukiyah, I. Syafri, J.B. Winarto, M.R.B. Susilo, A. Saputra, and E. Nurfadli, "Active faults and their implications for regional development at the southern part of West Java, Indonesia." Proceeding of FIG Working Week in Christchurch, New Zealand 2-6 May, 2016. 